\title{
Integration of elemental and isotope data supports a Neoproterozoic Adamastor Ocean realm
}

\author{
F.A. Caxito ${ }^{\text {* }}$, M. Heilbron ${ }^{2}$, C.M. Valeriano², H. Bruno ${ }^{2}$, A. Pedrosa-Soares ${ }^{1}$, \\ F.F. Alkmim ${ }^{3}$, F. Chemale ${ }^{4}$, L.A. Hartmann ${ }^{5}$, E. Dantas ${ }^{6}$, M.A.S. Basei ${ }^{7}$
}

Abstract

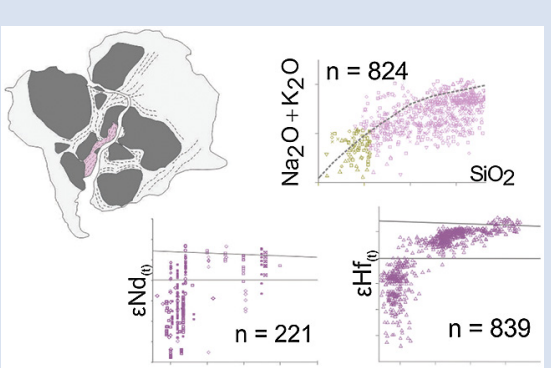

A robust elemental and isotopic dataset from Neoproterozoic igneous rocks discloses protracted consumption of oceanic lithosphere in the 3,000 km long orogenic system of southeastern South America. Time dependent isotopic variation trends suggest that Tonian-Cryogenian magmatic rocks formed in intra-oceanic supra-subduction settings, followed by Ediacaran magmatic arc building along Andean-type continental margins. Tectonic slices of basic-ultrabasic rocks associated with deep sea and exhalative rocks are interpreted as remnants of obducted oceanic lithosphere. Protracted closure of the oceanic realm resulted in a Himalayas-sized orogenic belt during Ediacaran-Cambrian collision, as recorded by voluminous aluminum-rich syn-collisional granites followed by post-collisional intrusions. The duration and rates of crust forming processes in island arc, continental margins and collisional settings imply that a vast Adamastor oceanic realm was consumed to form western Gondwana.

Received 23 September 2020 | Accepted 6 January 2021 | Published 11 February 2021

\section{Introduction}

The Cretaceous breakup of Gondwana in the South Atlantic region produced an asymmetric division of the Neoproterozoic Brasiliano/Pan-African Orogen (Fig. 1a,b) (Cordani et al., 2003). A large part of the orogen remained in South America as the $3,000 \mathrm{~km}$ long and $100-500 \mathrm{~km}$ wide Mantiqueira Province (Almeida et al., 1981) (Fig. 1a).

Early postulations of tectonic evolution of the Mantiqueira Province emphasised intra-continental models (e.g., Torquato and Cordani, 1981; Porada et al., 1989), an interpretation that received renewed attention in recent years (Cavalcante et al., 2019; Meira et al., 2019; Fossen et al., 2020; Konopásek et al. 2020). However, a wealth of field, geochemical and geochronological data produced in recent decades progressively prompted interpretations involving distinct stages of typical Wilson cycle processes involved in the closure of the Adamastor Ocean (originally defined by Hartnady et al., 1985). Besides reworked Archean-Palaeoproterozoic basement, Neoproterozoic continental rift and passive margin successions, ocean floor assemblages and syn-orogenic basins were described. Those are intruded by large volumes of Cryogenian to Cambrian plutonic rocks typical of pre-collisional, collisional, and post-collisional stages (Fig. 1a), with temporal and spatial ordering leading to the present unraveling of a simple and reliable interpretation of a complete rift-drift-subduction-collision plate tectonic cycle. The archetypical examples of intracontinental orogens (Raimondo et al., 2014), as proposed in the last century and recently revived, lack many of the tectonic components recognised in the last decades in the Mantiqueira Province.

Here we provide a new interpretation for a comprehensive database of 1,583 Hf-in-zircon (839 from Neoproterozoic, 744 from Archean-Palaeoproterozoic basement), $358 \mathrm{Sm}-\mathrm{Nd}$ isotope (221 and 137) and 824 bulk rock elemental geochemistry determinations of Neoproterozoic plutonic and volcanic rocks of the Mantiqueira Province (Supplementary Information), and demonstrate that these rocks are a testimony to an oceanic realm that was consumed to generate a Himalayas-sized orogen.

\section{Tonian-Cryogenian assemblages with Volcanic Arc Signatures}

Tonian-Cryogenian tonalite-granodiorite orthogneisses with dioritic to mafic enclaves represent an expanded series of calcalkaline, magnesian, metaluminous, I-type magmas along tholeiitic basalt (Fig. 1c-f). The 835-860 Ma Serra da Prata Complex of the central province has whole rock $\varepsilon \mathrm{Nd}_{(\mathrm{t})}$ from +6.4 to +0.9

\footnotetext{
Universidade Federal de Minas Gerais, CPMTC-IGC, Belo Horizonte, 31270-901 MG, Brazi

Universidade do Estado do Rio de Janeiro, Faculdade de Geologia, Rio de Janeiro, 20559-900 RJ, Brazil

Universidade Federal de Ouro Preto, Departamento de Geologia, Ouro Preto, 35400-000 MG, Brazil

Universidade do Vale do Rio dos Sinos, Faculdade de Geologia, São Leopoldo, 93022-750 RS, Brazil

Universidade Federal do Rio Grande do Sul, Instituto de Geociências, Porto Alegre, 91501-970 RS, Brazil

Universidade de Brasília, Laboratório de Geocronologia, Brasília, 70910-900 DF, Brazil

Universidade de São Paulo, CPGeo-IGC, São Paulo, 05508-080 SP, Brazil

Corresponding author (email: caxito@ufmg.br)
} 

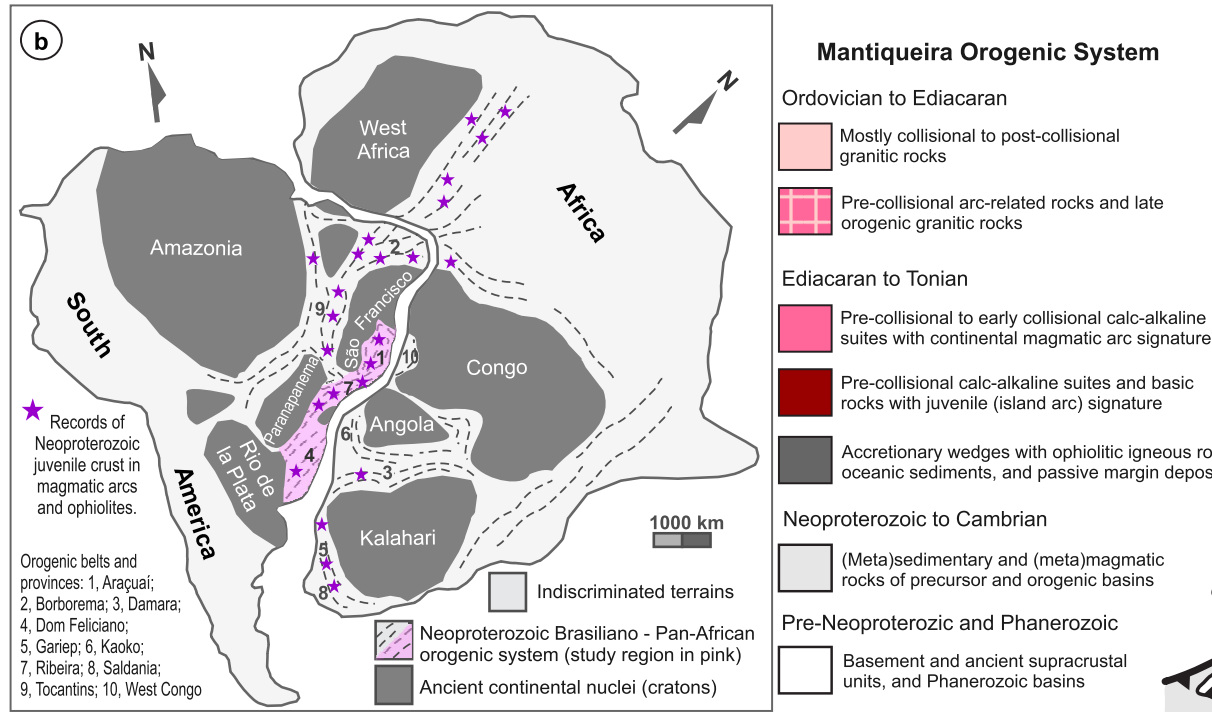

(c)

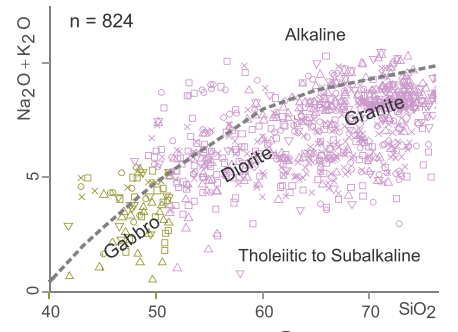

ब.

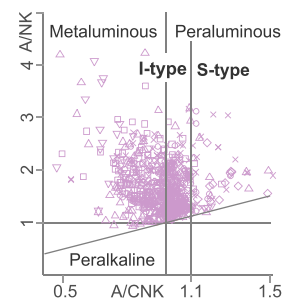

(e)
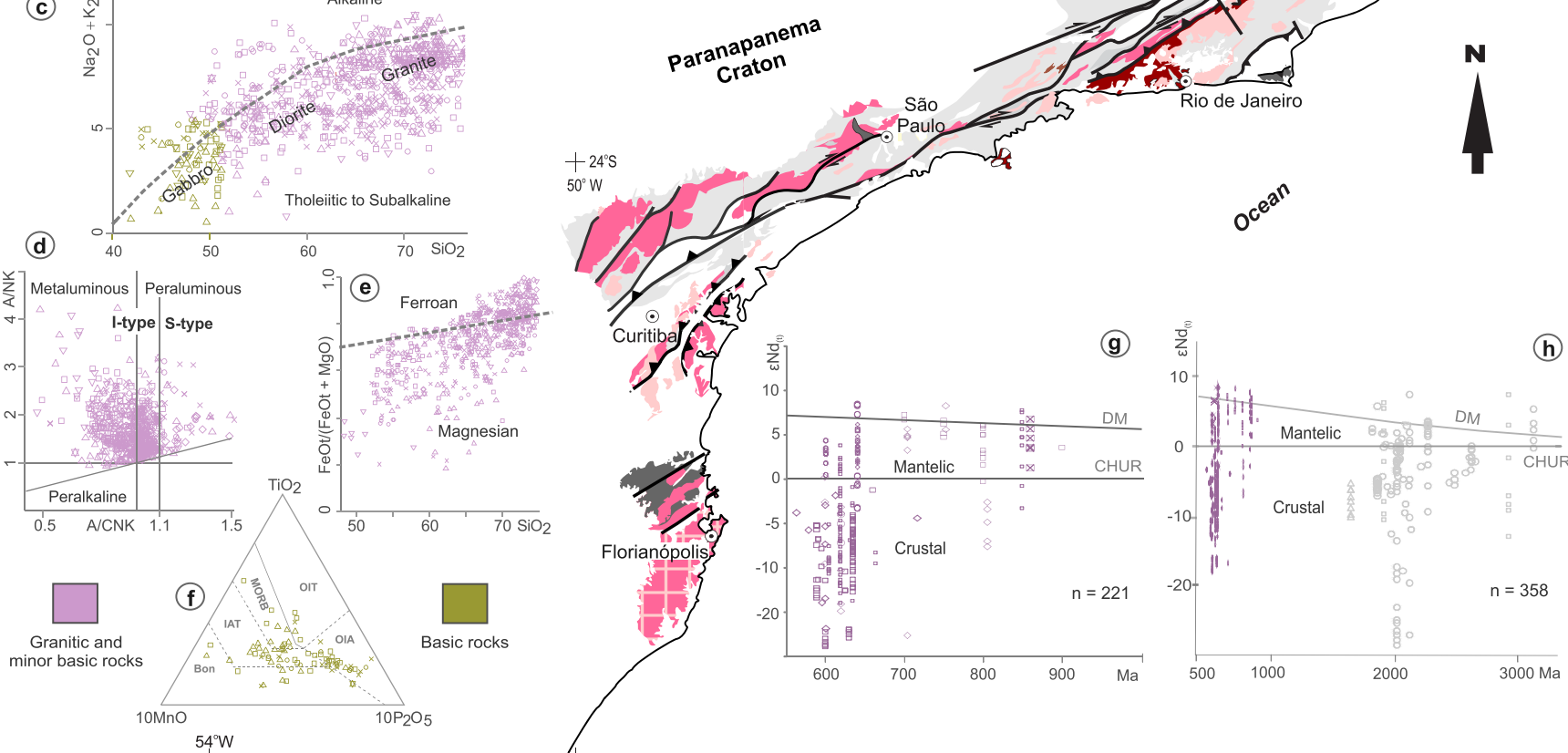

(h)
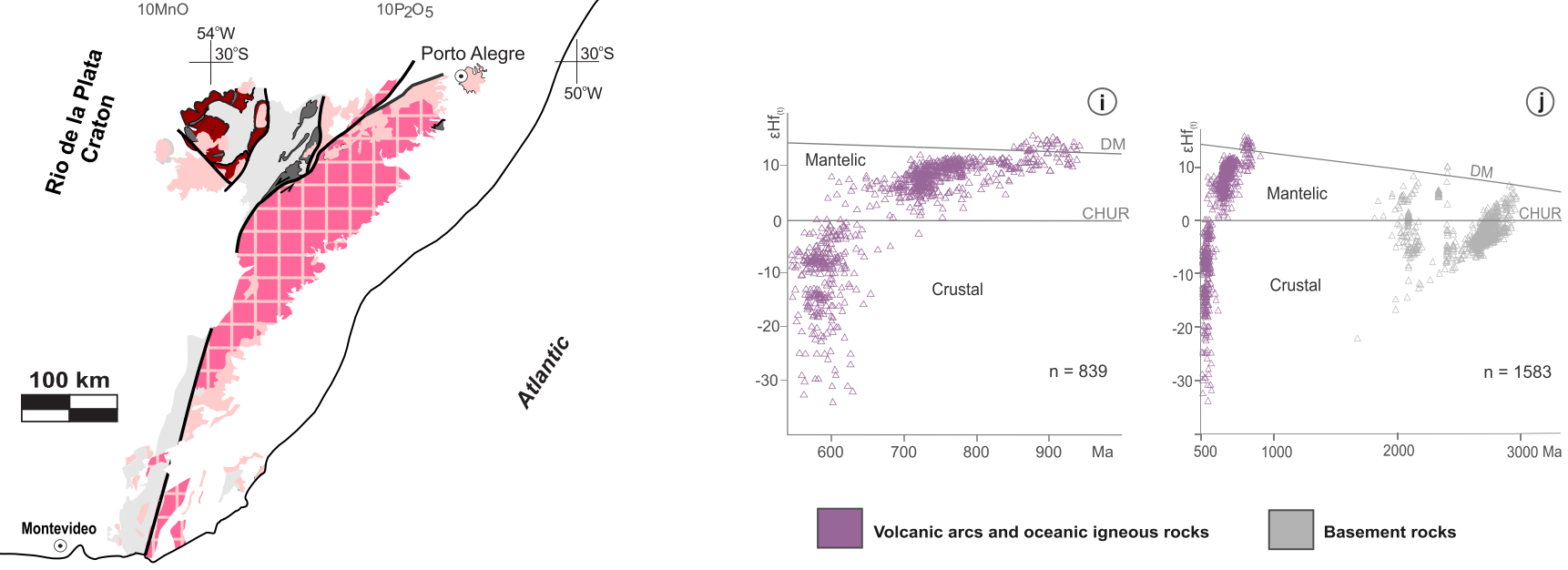

Figure 1 (a) Geological map of the Mantiqueira Province of southeastern South America in the context of (b) West Gondwana, with (c-f) elemental and (g-j) isotopic data from basic to felsic plutonic rocks and mafic-ultramafic bodies (see Supplementary Information for sources and references).

with $\mathrm{T}_{\mathrm{DM}} \mathrm{Nd}$ of $860-1,200 \mathrm{Ma},{ }^{87} \mathrm{Sr} /{ }^{86} \mathrm{Sr}_{\mathrm{i}}<0.7035$, zircon $\varepsilon \mathrm{Hf}_{(\mathrm{t})}$ from +14 to +10 , and $\mathrm{T}_{\mathrm{DM}}$ Hf of $840-1,010 \mathrm{Ma}$ (Peixoto et al., 2017; Heilbron et al., 2020; Santiago et al., 2020). The Rio
Negro Complex comprises intermediate to felsic plutonic rocks $(620-790 \mathrm{Ma})$ with $\varepsilon \mathrm{Nd}_{(\mathrm{t})}$ from +5 to -3 and ${ }^{87} \mathrm{Sr} /{ }^{86} \mathrm{Sr}<0.705$, as well as high $\mathrm{K}$ calc-alkaline to shoshonitic felsic rocks 
$(605-620 \mathrm{Ma})$ with $\varepsilon \mathrm{Nd}_{(\mathrm{t})}=-3$ to -14 and ${ }^{87} \mathrm{Sr} /{ }^{86} \mathrm{Sr}=0.7050$ 0.7100 (Tupinambá et al., 2012).

The São Gabriel terrane in the southern region (Fig. 1a) yielded U-Pb zircon ages of 800-860 Ma and 680-770 Ma (Babinski et al., 1996; Saalmann et al., 2005). Sm-Nd $\mathrm{T}_{\mathrm{DM}}$ are at 800-1,000 Ma with $\varepsilon \mathrm{Nd}_{(\mathrm{t})}$ on the depleted mantle curve (up to +8 , Babinski et al., 1996; Saalmann et al., 2005) and zircon $\varepsilon \mathrm{Hf}_{(\mathrm{t})}$ from +14 to +8 (Cerva-Alves et al., 2020).

\section{Ediacaran Assemblages with Volcanic Arc Signatures}

Widespread Ediacaran (mainly ca. 580-630 Ma) magmatic rocks represent an expanded series of medium to high $\mathrm{K}$ calc-alkaline, magnesian, metaluminous, I-type tonalites to granodiorites rich in dioritic to mafic enclaves, with minor gabbro (Fig. 1a) (Tedeschi et al., 2016; Basei et al., 2018; Corrales et al., 2020). The Rio Doce plutonic and volcanic rocks show $\varepsilon \mathrm{Nd}_{(\mathrm{t})}$ of -2.9 to -13.6 with $\mathrm{T}_{\mathrm{DM}} \mathrm{Nd}$ of $1,190-2,030 \mathrm{Ma},{ }^{87} \mathrm{Sr} /{ }^{86} \mathrm{Sr}$ of 0.7059 0.7165 and zircon $\varepsilon \mathrm{Hf}_{(\mathrm{t})}$ of +2.3 to -11.7 (Tedeschi et al., 2016; Degler et al., 2017; Novo et al., 2018; Araújo et al., 2020; Corrales et al., 2020). The Pelotas-Florianópolis-Aiguá batholith forms a multi-intrusion geological structure consisting of granite, gabbro and diorite with ${ }^{87} \mathrm{Sr} /{ }^{86} \mathrm{Sr}_{\mathrm{i}}$ ratios of $c a$. $0.712, \varepsilon \mathrm{Nd}$ of -3.6 to -22.2 and $\mathrm{T}_{\mathrm{DM}} \mathrm{Nd}$ of 1,200-2,400 Ma (Babinski et al., 1997; Koester et al., 2016).

\section{Neoproterozoic Basic-Ultrabasic Assemblages}

Accretionary mélanges of the northern province (Fig. 1a) include MORB chemistry metabasalt, banded metadolerite, metagabbro and meta-ultramafic rocks, with $\varepsilon \mathrm{Nd}_{(\mathrm{t})}$ up to +6.3 (PedrosaSoares et al., 1998; Amaral et al., 2020). Rootless plagiogranite veins hosted by a banded metadolerite are dated at $645 \pm$ 10 Ma (Amaral et al., 2020).

Mafic-ultramafic rock associations in the central sector include dunite cumulates, MORB- and IAT-like gabbro, metabasic rocks with sheeted dikes, pillow lavas and chert, emplaced at ca. $630 \mathrm{Ma}$ (Tassinari et al., 2001; Passarelli et al., 2018).

The 715-920 Ma MORB chemistry mafic-ultramafic assemblages in the southern sector have zircon $\varepsilon \mathrm{Hf}_{(t)}$ up to +15 and mantle-like trace element signatures (Arena et al., 2017, 2018; Hartmann et al., 2019). Dravite in altered oceanic crust has typical ocean floor $\delta^{11} \mathrm{~B}$ up to +1.8 (Hartmann et al., 2019). The southernmost ophiolites show whole rock $\varepsilon \mathrm{Nd}_{(\mathrm{t})}$ up to +8.5 (Peel et al., 2018; Ramos et al., 2020) (Fig. 1a).

\section{Discussion}

The time dependent variation of isotopic trends (Fig. 1g-j) is interpreted as a shift from Tonian-Cryogenian juvenile settings fingerprinting intra-oceanic arcs to Ediacaran settings with magmas formed by mixing of mantle wedge melts and anatectic melts from both the Tonian-Cryogenian rocks and the Archean-Palaeoproterozoic basement. The resulting mixed melts intruded active continental margin settings similar to Andean volcanic arcs. The protracted consumption of oceanic lithosphere is required, and this is attested by the associated ophiolites along the entire length of the Mantiqueira Province.

Recently revisited models of intracontinental orogeny focused on a "space problem" for the development of an Adamastor oceanic realm based on estimates of maximum oceanic width using modern spreading and subduction rates (Fossen et al., 2020; Konopásek et al., 2020). However, those estimates are contingent and cannot be used as hard proof against mobilistic models, because: 1) the ocean was probably fragmented in smaller sub-domains such as in the present day western Pacific and also connected to a much large Neoproterozoic oceanic system (Cordani et al., 2003) (Fig. 1b); 2) the Neoproterozoic upper mantle was warmer, leading to distinct spreading and subduction rates and dynamics (Brown, 2014); 3) intense wrench tectonics with thousands-of-km long shear zones obliterated former low angle surfaces and displaced allochthonous units far from their original position; 4) age, size and time span of an ocean have little significance in determining whether subduction is feasible or not (Hall, 2019), while lithospheric weaknesses such as magma-rich rift systems present in the orogen precursor basins (Tack et al., 2001; Basei et al., 2008) might play a major role in subduction initiation (Stern and Gerya, 2018); 5) those calculations use a palinspastic incorrect pre-drift reconstruction, ignoring at least $c a .280 \mathrm{~km}$ of restored continental crust now stretched in the Brazilian and African passive margins (Aslanian et al., 2009); 6) the termination of the orogen in a gulf partially enclosed by continental crust implies much lower convergence rates; and 7) non-Euclidean geometry implies the diachronous along strike opening and closure of oceanic basins. Thus, calculations of former oceanic width are interesting hypothetical exercises, but the field, petrographic, isotopic, elemental and geochronological data sets cannot be considered as subordinated to it.

The striking coherence of evidence from various geological disciplines (detailed field, petrographic and structural studies, bulk rock chemistry, isotope geochemistry, quantitative geothermobarometry and petrology) support a solid interpretation for the tectonic units and their arrangement in time and space to be explained better through the development and consumption of an oceanic realm in the Mantiqueira Province. The evidence provided here suggests that the main ocean was located to the west of the arc rocks, where recently paired HP-HT metamorphic belts were described (Ricardo et al., 2020). The original proposition of Hartnady et al. (1985) would correspond to the Marmora back-arc basin in the African counterparts, east of the Pelotas arc (Frimmel et al., 2011; Basei et al., 2018).

\section{Acknowledgements}

We dedicate this article to the memory of Koji Kawashita, a pioneering, devoted scientist who dedicated his career to the implementation of many isotope geology laboratories in Brazil. The authors acknowledge the Brazilian Scientific and Technological Development Council (CNPq) for their research grants. Comments by Craig Storey and Hartwig Frimmel are acknowledged. This is a contribution to Project MOBILE (geolifemobile.com) supported by Instituto Serrapilheira (Serra-1912-31510).

Editor: Horst R. Marschall

\section{Additional Information}

Supplementary Information accompanies this letter at https:// www.geochemicalperspectivesletters.org/article2106.

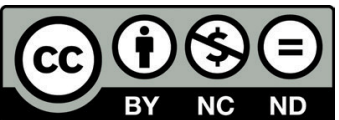

(C) 2021 The Authors. This work is distributed under the Creative Commons Attribution NonCommercial No-Derivatives 4.0 License, which permits unrestricted distribution provided the 
original author and source are credited. The material may not be adapted (remixed, transformed or built upon) or used for commercial purposes without written permission from the author. Additional information is available at https://www. geochemicalperspectivesletters.org/copyright-and-permissions.

Cite this letter as: Caxito, F.A., Heilbron, M., Valeriano, C.M., Bruno, H., Pedrosa-Soares, A., Alkmim, F.F., Chemale, F., Hartmann, L.A., Dantas, E., Basei, M.A.S. (2021) Integration of elemental and isotope data supports a Neoproterozoic Adamastor Ocean realm. Geochem. Persp. Let. 17, 6-10.

\section{References}

Almeida, F.F.M., Hasui, Y., Brito Neves, B.B., FucK, R.A. (1981) Brazilian structural provinces: an introduction. Earth-Science Reviews 17, 1-29.

Amaral, L., Caxito, F.A., Pedrosa-Soares, A.C., Queiroga, G., Babinski, M., Trindade, R., Lana, C., Chemale, F. (2020) The Ribeirão da Folha ophiolite-bearing accretionary wedge (Araçuaí orogen, SE Brazil): new dat for Cryogenian plagiogranite and metasedimentary rocks. Precambrian Research 336, 105522

Araújo, C., Pedrosa-Soares, A., Lana, C., Tedeschi, M., Dussin, I. (2020) Primeiro registro de magmatismo juvenil no arco magmático Rio Doce, Orógen Araçuaí meridional. In: XVII Simpósio Nacional de Estudos Tectônicos (SNET), SBG, Bento Gonçalves, Annals, 105.

ARENA, K.R., HARTMAnN, L.A., LANA, C. (2017) Tonian emplacement of ophiolites in the southern Brasiliano Orogen delimited by U-Pb-Hf isotopes of zircon from metasomatites. Gondwana Research 49, 296-332.

Arena, K.R., Hartmann, L.A., Lana, C. (2018) U-Pb-Hf isotopes and trace element of metasomatic zircon delimit the evolution of neoproterozoic Capane ophiolite in the southern Brasiliano Orogen. International Geology Review 60, 911-928

Aslanian, D., Moulin, M., Olivet, J. L., Unternehr, P., Matias, L., Bache, F., Rabineau, M., Nouzé, H., Klingelheofer, F., Contrucci, I., Labails, C. (2009) Brazilian and African passive margins of the Central Segment of the South Atlantic Ocean: Kinematic constraints. Tectonophysics 468, 98-112.

Babinski, M., Chemale, F., Hartmann, L.A., Van Schmus, W.R., Silva, L.C. (1996) Juvenile accretion at 750-700 Ma in southern Brazil. Geology 24, 439-442.

Babinski, M., Chemale, F., Van Schmus, W.R., Hartmann, L.A., Silva, L.C. (1997) $\mathrm{U}-\mathrm{Pb}$ and $\mathrm{Sm}-\mathrm{Nd}$ geochronology of the neoproterozoic granitic-gneissic Dom Feliciano Belt, southern Brazil. Journal of South American Earth Sciences 10, 263-274.

Basei, M.A.S., Frimmel, H.E., Nutman, A.P., Preciozzi, F. (2008) West Gondwana amalgamation based on detrital zircon ages from Neoproterozoic Ribeira and Dom Feliciano belts of South America and comparison with coeval sequences from SW Africa. Geological Society, London, Special Publications 294, 239-256.

Basei, M.A.S., Frimmel, H.E., Campos Neto, M.C., Ganade de Araújo, C.E. CAstro, N.A., PAssarelli, C.R. (2018) The tectonic history of the southern Adamastor Ocean based on a correlation of the Kaoko and Dom Feliciano belts. In: Siegesmund S., Basei M., Oyhantçabal P., Oriolo S. (Eds.) Geology of Southwest Gondwana. Regional Geology Reviews. Springer, Cham., 63-85.

Brown, M. (2014) The contribution of metamorphic petrology to understanding lithosphere evolution and geodynamics. Geoscience Frontiers 5, 553-569.

Cavalcante, C., Fossen, H., Almeida, R P., Hollanda, M.H.B., Egrdio-Silva, M. (2019) Reviewing the puzzling intracontinental termination of the Araçuaí-West Congo orogenic belt and its implications for orogenic development. Precambrian Research 322, 85-98.

Cerva-Alves, T., Hartmann, L.A., Remus, M.V.D., Lana, C. (2020) Integrated ophiolite and arc evolution, southern Brasiliano Orogen. Precambrian Research 341, 105648

Cordani, U.G., Brito Neves, B.B., D'Agrella-Filho, M.S. (2003) From Rodinia to Gondwana: a review of the available evidence from South America. Gondwana Research 6, 275-283.

Corrales, F.F., Dussin, I.A., Heilbron, M., Bruno, H. Bersan, S, Valeriano, C.M Pedrosa-Soares, A.C., Tedeschi, M. (2020) Coeval high Ba-Sr arc-related and OIB Neoproterozoic rocks linking pre-collisional magmatism of the Ribeira and Araçuaí orogenic belts, SE-Brazil. Precambrian Research 337 105476

Degler, R.，Pedrosa-Soares，A., Dussin， I., Queiroga， G.，Schulz，B. (2017) Contrasting provenance and timing of metamorphism from paragneisses of the Araçuaí-Ribeira orogenic system, Brazil: Hints for Western Gondwana assembly. Gondwana Research 51, 30-50.

Fossen, H., Cavalcante, C., Konopásek, J., Meira, V.T., Almeida, R.P., Hollanda, M.H.B., Trompette, R. (2020) A critical discussion of the subduction-collision model for the Neoproterozoic Araçuaí-West Congo orogen. Precambrian Research 343, 105715.

Frimmel, H.E., BaSEI, M.S., GAUCHER, C. (2011) Neoproterozoic geodynamic evolution of SW-Gondwana: a southern African perspective. International Journal of Earth Sciences 100, 323-354.

Hall, R. (2019) The subduction initiation stage of the Wilson cycle. Geological Society, London, Special Publications 470, 415-437.

Hartmann, L.A., Werle, M., Michelin, C.R.L., Lana, C., Queiroga, G., Castro, M.P., Arena, K.R. (2019) Proto-Adamastor ocean crust (920 Ma) described in Brasiliano Orogen from coetaneous zircon and tourmaline. Geoscience Frontiers 10, 1623-1633.

Hartnady, C., Joubert, P., Stowe, C. (1985) Proterozoic crustal evolution in southwestern Africa. Episodes 8, 236-244.

Heilbron, M., Valeriano, C.M., Peixoto, C., Tupinambá, M., Neubauer, F., Dussin, I., Corrales, F., Bruno, H., Lobato, M., Almeida, J.C.H., Silva, L.G.E. (2020) Neoproterozoic magmatic arc systems of the central Ribeira belt, SE-Brazil, in the context of the West-Gondwana pre-collisional history: A review. Journal of South American Earth Sciences, 102710.

Koester, E., Porcher, C. C., Pimentel, M. M., Fernandes, L.A.D., VignolLelarge, M.L., Oliveira, L.D., Ramos, R.C. (2016) Further evidence of 777 Ma subduction-related continental arc magmatism in Eastern Dom Feliciano Belt, southern Brazil: the Chácara das Pedras Orthogneiss. Journal of South American Earth Sciences 68, 155-166.

KonopáseK, J., CAVAlcante, C., Fossen, H., JanoušEK, V. (2020) Adamastor-an ocean that never existed?. Earth-Science Reviews 205, 103201

Meira, V.T., Garcia-Casco, A., Hyprolito, T., Juliani, C., Schorscher, J.H.D. (2019) Tectono-Metamorphic Evolution of the Central Ribeira Belt, Brazil: A Case of Late Neoproterozoic Intracontinental Orogeny and Flow of Partially Molten Deep Crust During the Assembly of West Gondwana. Tectonics 38, 3182-3209.

Novo, T.A., Pedrosa-Soares, A., Vieira, V.S., Dussin, I., Silva, L.C. (2018) The Rio Doce Group revisited: an Ediacaran arc-related volcano-sedimentary basin, Araçuaí orogen (SE Brazil). Journal of South American Earth Sciences 85, 345-361.

Passarelli, C.R., Basei, M.A.S., Siga JR., O., Harara, O.M.M. (2018) The Luis Alves and Curitiba terranes: continental fragments in the Adamastor Ocean. In: Siegesmund S., Basei M., Oyhantçabal P., Oriolo S. (Eds) Geology of Southwest Gondwana. Regional Geology Reviews. Springer, Cham., 189-215.

Pedrosa-Soares, A., Vidal, P., Leonardos, O.H., Brito Neves, B.B. (1998) Neoproterozoic oceanic remnants in eastern Brazil: further evidence and refutation of an exclusively ensialic evolution for the Araçuaí-West Congo orogen. Geology 26, 519-522.

Peel, E., Sanchez-Bettucci, L., Basei, M.A.S. (2018) Geology and geochronology of Paso del Dragón Complex (northeastern Uruguay): Implications on the evolution of the Dom Feliciano Belt (Western Gondwana). Journal of South American Earth Sciences 85, 250-262.

Peixoto, C.A., Heilbron, M., Ragatky, D., Armstrong, R., Dantas, E., VAleriano, C.M., SimonetTI, A. (2017) Tectonic evolution of the Juvenile Tonian Serra da Prata magmatic arc in the Ribeira belt, SE Brazil: Implications for early west Gondwana amalgamation. Precambrian Research 302, 221-254.

Porada, H. (1989) Pan-African rifting and orogenesis in southern to equatorial Africa and eastern Brazil. Precambrian Research 44, 103-136.

Ramos, R.C., Koester, E., Vieira, D.T. (2020) Sm-Nd systematics of metaultramaficmafic rocks from the Arroio Grande Ophiolite (Brazil): Insights on the evolution of the South Adamastor paleo-ocean. Geoscience Frontiers, doi: 10.1016/j.gsf.2020.02.013.

Raimondo, T., Hand, M., Collins, W.J. (2014) Compressional intracontinental orogens: Ancient and modern perspectives. Earth-Science Reviews 130, $128-153$.

Ricardo, B.S., Faleiros, F.M., Moraes, R., Siga Jr., O., Campanha, G.A. (2020) Tectonic implications of juxtaposed high-and low-pressure metamorphic field gradient rocks in the Turvo-Cajati Formation, Curitiba Terrane, Ribeira Belt, Brazil. Precambrian Research, 105766.

Saalmann, K., Hartmann, L.A., Remus, M.V.D., Koester, E., Conceição, R.V. (2005) Sm-Nd isotope geochemistry of metamorphic volcanosedimentary successions in the São Gabriel Block, southernmost Brazil: evidence for the existence of juvenile Neoproterozoic oceanic crust to the east of the Rio de la Plata craton. Precambrian Research 136, 159-175. 
Santiago, R., Caxito, F.A., Pedrosa-Soares, A., Neves, M., Dantas, E. (2020) Tonian island arc remnants in the northern Ribeira orogeny of western Gondwana: The Caxixe batholith (Espírito Santo state, SE Brazil). Precambrian Research 351, 105944.

SteRN, R.J., GERYA, T. (2018) Subduction initiation in nature and models: A review. Tectonophysics 746, 173-198.

Tack, L., Wingate, M.T.D., Liégeois, J.P., Fernandez-Alonso, M., Deblond, A (2001) Early Neoproterozoic magmatism (1000-910 Ma) of the Zadinian and Mayumbian Groups (Bas-Congo): onset of Rodinia rifting at the western edge of the Congo craton. Precambrian Research 110, 277-306.

Tassinari, C.C., Munhá, J.M., Ribeiro, A., CorreiA, C.T. (2001) Neoproterozoic oceans in the Ribeira Belt (southeastern Brazil): The Pirapora do Bom Jesus ophiolitic complex. Episodes, 24, 245-251.

Tedeschi, M., Pedrosa-Soares, A., Dussin, I., Tassinari, C., Silva, L.C., Gonçalves, L.E., AlKmim, L., Lana, C., Figueiredo, C., Dantas E. Medeiros, S., Campos, C., Corrales, F., Heilbron, M. (2016) The Ediacaran Rio Doce magmatic arc revisited (Araçuaí-Ribeira orogenic system, SE Brazil). Journal of South American Earth Sciences 68, 167-186.

Torquato, J.R., CoRDANI, U.G. (1981) Brazil-Africa geological links. Earth-Science Reviews 17, 155-176.

Tupinambá, M., Heilbron, M., Valeriano, C., Porto Jr., R., Dios, F.B., Machado, N., Silva, L.G.E., AlmeidA, J.C.H. (2012) Juvenile contribution of the Neoproterozoic Rio Negro magmatic arc (Ribeira Belt, Brazil): implication for western Gondwana amalgamation. Gondwana Research 21, 422-438. 